\title{
Early polished stone tools in South China evidence of the transition from Palaeolithic to Neolithic
}

\author{
Chaohong Zhao, Xiaohong $\mathbf{W u}^{*}$, Tao Wang, Xuemei Yuan \\ School of Archaeology and Museology, Peking University, Beijing, China \\ *wuxh@pku.edu.cn
}

\begin{abstract}
The appearance of polished stone tools has been taken as one of the important indicators of the beginnings of the Neolithic. Early polished stone tools excavated in South China are discussed in this paper. The polishing technology developed from stone tools with polished blades to whole polished stone tools. Different kinds of polished stone tools appeared at different times. The earliest polished stone tools are axes, adzes and cutters, with only the blades polished. They date to 21000 $19000 \mathrm{cal} \mathrm{BP}$. The whole polished stone tools appeared thousands of years later. The relationship of the polishing technology with other factors during the transition from the Paleolithic to the Neolithic should be discussed after more detailed information has been obtained.
\end{abstract}

IZVLEČEK - Pojav poliranih kamenih orodij je eden glavnih znakov za začetek neolitika. V članku obravnavamo zgodnje polirano kameno orodje, ki smo ga izkopali na jugu Kitajske. Tehnologija poliranja se je razvijala od kamenih orodij s poliranim rezilom do v celoti poliranega kamenega orodja. Najzgodnejše polirano kameno orodje so sekire in sekači, ki imajo polirano le rezilo. Datirano je v čas od 21000 do 19000 calBP. V celoti polirano kameno orodje se pojavi tisočletja kasneje. Povezava med tehnologijo poliranja in drugimi dejavniki prehoda iz paleolitika v neolitik bo mogoča, ko bomo imeli več podrobnejših podatkov.

KEY WORDS - China; Palaeolithic; Neolithic; polished stone tools

\section{INTRODUCTION}

Because of its eco-geographical diversity and archaeological/cultural complexity China is now becoming more important to serve as a source for the research of constructing new analytical methodologies for properly understanding the Palaeolithic-Neolithic transition. The research on the models of Neolithization in China is still in the early stages. In this paper, we focus on early polished stone tools excavated in South China in order to investigate more detailed information about Neolithization.

The function of polished stone tools has been discussed since the middle of the $19^{\text {th }}$ century when a French archaeologist divided stone tools into chipped ones and ground ones. The ground lithic implements were accepted as one important characteristic of the Neolithic by archaeologists and prehistorians following a book published in 1865 in which the late period of polished stone tools was regarded as part of the Neolithic period. The appearance of polished stone tools has been taken as one of the indicators of the beginning of the Neolithic ages for some time (Glyn Daniel 1987) and some archaeological scholars still insist that their appearance is what distinguishes the Neolithic from the Paleolithic. In fact, abundant materials excavated in recent decades reveal that new models will be required to describe the transitional period. The ground or polishing technologies were not only applied to stone, but also to wooden tools. These tools were used various activities: agriculture, fishing, hunting, food processing and weaving etc. It is difficult to correlate them with different (micro)regional cultural backgrounds and environmental conditions. The cul- 
tural trends in China can be divided into two geological regions, South China and North China, during the Paleolithic-Neolithic transition. In this paper, we investigate early polished stone tools found in South China.

\section{THE EARLY POLISHED STONE TOOLS FOUND IN SOUTH CHINA}

In the last 20 years, many important sites have been excavated in China, which provided plenty of materials for researching the Paleolithic-Neolithic transition. According to excavation reports, more than 10 archaeological sites dated to ten thousand years ago have been found with polished stone tools. Most are cave sites, except the Liyuzui in Dalongtan and Shangshan in Zejiang, which are open-air sites. Typical sites are listed in Table. 1. The polished stone tools mentioned here include axes, adzes, chisels, knives, sickles, spearheads, and arrowheads. Stone rollers, stone saddle-querns and perforated ground stone tools should not be included among the polished stone tools. So the earliest polished stone tool in Figure 1.1 is the polished peddle cutter from the west layer No. 4 at Bailiandong cave site in Liuzhou (Scientific Museum of Liuzhou Bailiandong Cave 1987; Liuzhou Museum 1983). This cutter is $4.5 \mathrm{~cm}$ long, $2.7 \mathrm{~cm}$ wide and $1.2 \mathrm{~cm}$ thick and made of metamorphic siltstone. A flat small peddle was ground, which formed an inclined arc-shaped knife-edge. The whole artifact is in the form of a triangle. The uncalibrated radiocarbon dates assigned to the west layer No. 4 are $19350 \pm 180 \mathrm{BP}$ and $20960 \pm 150 \mathrm{BP}$. A stone adze with polished blade or adze-shaped cutter (Fig. 1.2) was excavated from the east layer No. 4. It was made from an arc-topped, flat trapezoidal pebble of quartz siltite by chopping and polishing the bottom to form the knife-edge. It is $8.3 \mathrm{~cm}$ long and $1.2 \mathrm{~cm}$ thick and the knife-edge is $5.1 \mathrm{~cm}$ wide. The uncalibrated radiocarbon age is $13170 \pm 590 \mathrm{BP}$ (Zhou Guoxing 1994).

The site of Liyuzui in Dalongtan can be divided into two cultural strata (Qiu Licheng et al. 1982). In the lower stratum most of the stone tools are chipped;

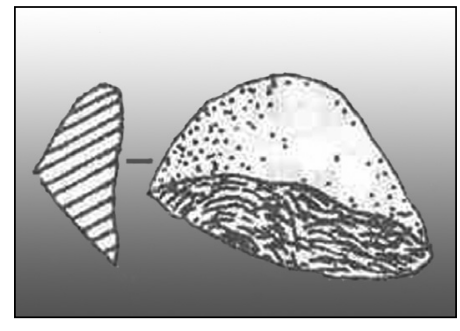

Fig. 1.1. Cutter with polishedblade from the Bailiandong site (Zhou Guoxing 1994).
Fig. 1.2. Adze with polishedblade from the Bailiandong site (Zhou Guoxing 1994).

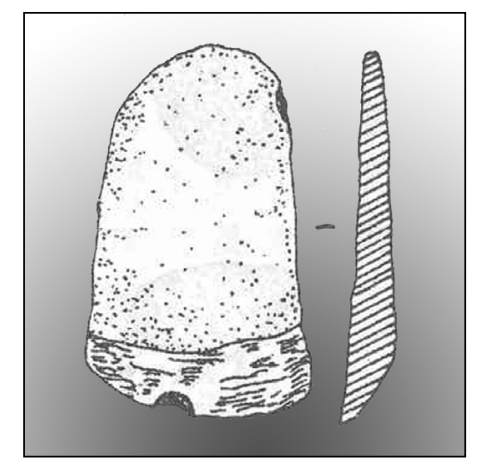

they were excavated with a few sandy pottery shards with corded decoration and lightly calcified animal bones. Only one polished stone tool was found, a stone axe with a polished blade (Fig. 2.1). The blade was polished on one side only. It is small and incomplete, $11 \mathrm{~cm}$ long and $5 \mathrm{~cm}$ wide in the middle. The lower layer of this site, which is $100-170 \mathrm{~cm}$ thick, should be divided into more sub-layers, but at present we can give the age of the polished stone axe within a range of uncalibrated radiocarbon dates as somewhere between $21025 \pm 450 \mathrm{BP}$ and $11450 \pm 150 \mathrm{BP}$.

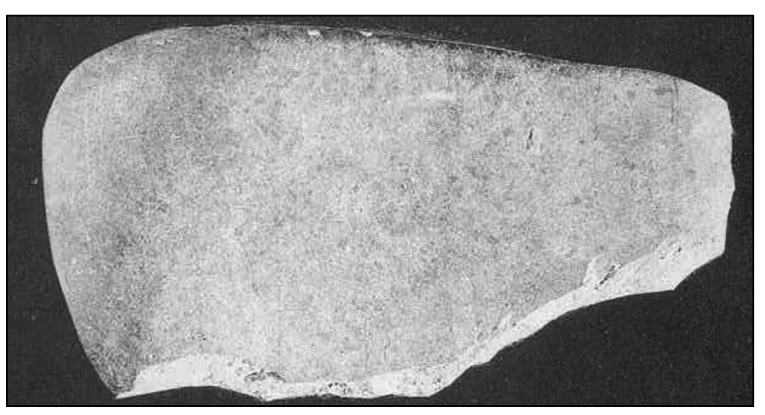

Fig. 2.1. Axe with polished blade from the Liyuzui site (Liuzhou Museum 1983).

The deposit at the Dushizai cave site is 4 meters thick, with five strata, and has been excavated four times from 1960 to 1983. Strata 2, 3, and 4 correspond to the upper, middle and lower cultural layers. Most stone tools are for chopping, with some ground perforated stoneware. The materials are sandstone, argillaceous rock, quartzose sandstone, quartzite and so on, with sandstone predominating. All of the 7 stone cutters with polished blades were excavated from the upper cultural layer. Their forms are not very uniform. Most of them are made from flakes and cores by chopping and polishing to form the blade. Cutter (Fig. 3.1) was made after chiseling and polishing the edge. It is $5.4 \mathrm{~cm}$ long and the blade is $3.2 \mathrm{~cm}$ wide. Its radiocarbon date without calibration is $12845 \pm 130 \mathrm{BP}$.

In the Huangyandong cave site beside chipped stone tools, a fragment of perforated stone ware, and in- 


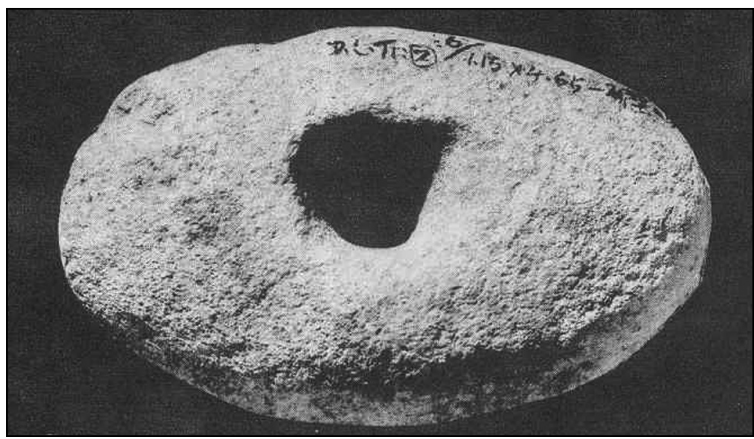

Fig. 2.2. Perforated stone ware from the Liyuzui site (Liuzhou Museum 1983).

complete polished stone tool were found. The remains of pig, deer, snails and shells have been recorded (Song Fangyi et al. 1983). The incomplete stone axe is made from quartzose fine sandstone, with a fine polished arc-shaped blade. The incomplete length of the axe is $6 \mathrm{~cm}$, with a $4.5 \mathrm{~cm}$ wide blade. The shells from this deposit gave uncalibrated radiocarbon dates from $10640 \pm 300 \mathrm{BP}$ to $11580 \pm$ $300 \mathrm{BP}$.

Xianrendong and Diaotonghua are two cave sites $800 \mathrm{~m}$ apart in the small and humid Dayuan Basin. Five excavations were carried out at Xianrendong from 1962 to 1999. Diaotonghuan was excavated in 1995. Abundant upper Paleolithic and early Neolithic cultural deposits were found at these two sites. The cultural deposits of the Stone Age were divided into two strata following excavations in 1962 and 1964. More strata were assigned to the deposit after 1995. According to the information from the excavation of 1962 and 1964, most stone tools are chipped (scrappers, choppers, cores, and plate-shaped artifacts) and embedded in the lower cultural layers (Jiangxi Provincal Committee for Administration of Cultural Relics 1963; Jiangxi Provincal Museum 1970). The polished stone tools assemblage consist of celts, shuttle shaped (Fig. 4.2) or cone-shaped (Fig. 4.1) wares and perforated stones (Fig. 4.3). They are made from roughly polished sandstone. The materials of the excavation after 1995 have not been published so far. But according to someone's

Fig. 3.1. Cutter with polishedblade from the Dushizai site (Qiu Licheng et al. 1982). introduction, there were 625 stone tools, 318 bone wares, 26 perforated shells, 516 pottery shards, tens pieces of human bone, and more than ten thousand pieces of animal bone excavated at the sites of Xianrendong and Diaotonghuan. Most of the stone tools are pebbles. A small number of them are flint and quartz flakers. There are scrapers, points, choppers, blades and micro-blades and several polished stone tools. There is no radiocarbon date related directly to layer F, in which the ground shuttle shaped stone

Fig. 3.2. Cutter with polishedblade from the Dushizai site (Qiu Licheng et al. 1982).

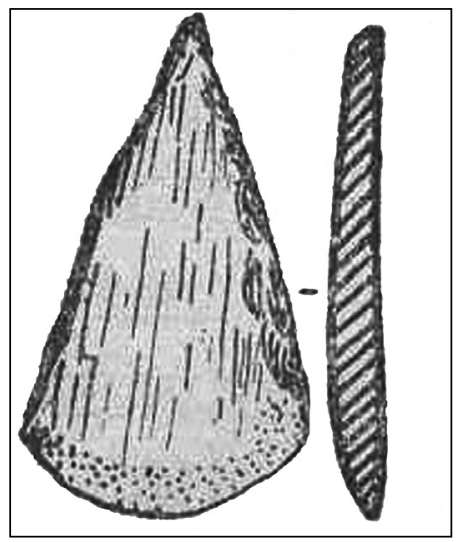

artifact and polished conical stone tool were found. The radiocarbon date of layer D is $15090 \pm 210 \mathrm{BP}$ (the calibrated age is 16900-15 300, BA00014) at the same site. So the radiocarbon date of the polished stone tools found in Layer F should be older than $15090 \pm 210$ BP. We can see very clear from

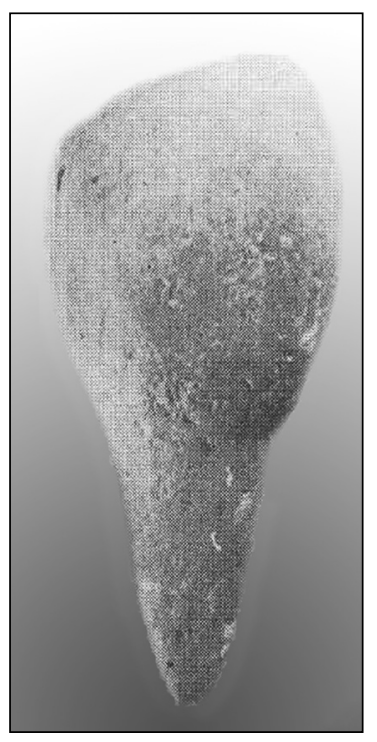

Fig. 4.1. Polished and tapered stone tools from the Xianrendong site (Jiangxi Provincal Committee for Administration of Cultural Relics 1963).

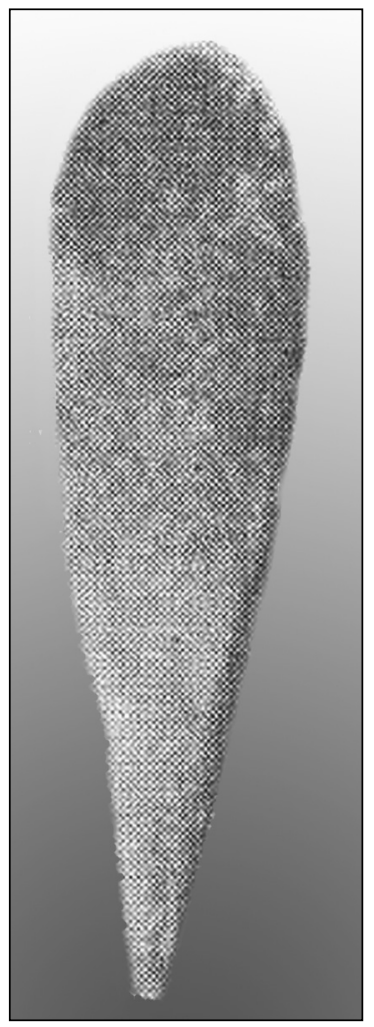


these two site that the early polished stone tools appeared earlier than the early pottery.

Shangshan site in Pujiang county in Zejiang province is a hill site excavated in 2001. There were abundant cultural remains with local cultural characteristics (Jiang Leping et al. 2003). The layers No. 3 to 7 are Neolithic, $40-50 \mathrm{~cm}$ thick. The typical wares are a stone ball, an irregular flat, and long rectangular roller, a large shaped stone saddle-quern and red surfaced pottery shards with charcoal tem- pering. There are wholly or partially polished adze, axe and perforated stone wares and flakers (Fig. 5). The rice husks in the pottery shards have yielded evidence of early cultivated rice. The radiocarbon dates from the rice husks are $9610 \pm 160$ uncal BP and $8050 \pm 110$ uncal BP.

Pengtoushan is a hill site by a river, excavated in 1988. The excavated relics are tombs and house remains, with a large quantity of stone wares, pottery shards, and rice. Most of the stone tools are chop-

\begin{tabular}{|c|c|c|c|c|c|}
\hline Stratum & Material & $\begin{array}{l}14 \mathrm{C} \text { age } \\
\text { (yr, BP) }\end{array}$ & $\begin{array}{l}\text { Calibrated age } \\
\text { Cal BP } \\
( \pm 2 \sigma, 95.4 \%)\end{array}$ & Lab code & Note \\
\hline \multicolumn{6}{|c|}{ Bailiandong in Liuzhou, Guangxi Province, Phase II } \\
\hline West No. 4 & Calc-sinter & $19345 \pm 180^{*}$ & $23950-22150$ & BK82097 & \multirow{3}{*}{$\begin{array}{l}\text { Peddle Cutter and adze shaped } \\
\text { cutter with polished-blade, asso- } \\
\text { ciated with chipped stone tools, } \\
\text { animal bones and shells. }\end{array}$} \\
\hline West No. 4 & Calc-sinter & $20965 \pm 150$ & & BK92039 & \\
\hline East No. 4 & Charcoal & $13165 \pm 590^{*}$ & $17250-14050$ & BK93017 & \\
\hline \multirow{2}{*}{ Layer No. 3} & \multirow{2}{*}{ Bone } & \multicolumn{2}{|c|}{$8700 \pm 240(\mathrm{~Pa}-231)$} & \multirow{2}{*}{ BKY82239 } & \multirow{2}{*}{ Polished axe } \\
\hline & & $8000 \pm 800(\mathrm{Tr}$ & 30) & & \\
\hline \multicolumn{6}{|c|}{ Liyuzui in Dalongtan County in Liuzhou, Guangxi Province } \\
\hline Lower & Shell & $22670 \pm 250^{*}$ & & BK82091 & \multirow{3}{*}{$\begin{array}{l}\text { Adze-shaped cutter with poli- } \\
\text { shed-blade, associated with chip- } \\
\text { ped stone tools, sandy terracotta, } \\
\text { shells. }\end{array}$} \\
\hline Lower & Shell & $20430 \pm 450^{*}$ & & PV0379(1) & \\
\hline Lower & Shell & $18035 \pm 300^{*}$ & $22450-20450$ & PV0379(2) & \\
\hline Upper & Shell & $12515 \pm 220^{*}$ & $15750-14050$ & BK82090 & \multirow{3}{*}{$\begin{array}{l}\text { Axe and adze with polished-blade } \\
\text { associated with sandy terracotta. }\end{array}$} \\
\hline Upper & Bone & $11450 \pm 150^{*}$ & $13850-13000$ & PV0402 & \\
\hline Upper & Bone & $10205 \pm 150^{*}$ & $12650-11250$ & PV0401 & \\
\hline \multicolumn{6}{|c|}{ Dushizai in Yangchun, Guangdong Province } \\
\hline Layer No. 4 & Bone & $16205 \pm 570^{*}$ & $20850-17850$ & BK83018 & \multirow{7}{*}{$\begin{array}{l}\text { Peddles with polished edge and } \\
\text { cutter with polished blade, asso- } \\
\text { ciated with perforated stone } \\
\text { wares and shells. }\end{array}$} \\
\hline Layer No. 3 lower & Bone & $14915 \pm 250^{*}$ & $18650-17050$ & BK83017 & \\
\hline Layer No. 3 lower & Shell & $16680 \pm 180^{*}$ & $20650-19050$ & BK83011 & \\
\hline Layer No. 3 upper & Bone & $13855 \pm 130^{*}$ & $17250-16050$ & BK83016 & \\
\hline Layer No. 3 upper & Shell & $17200 \pm 200^{*}$ & $21350-19650$ & BK83010 & \\
\hline Layer No. 3 upper & Shell & $14480 \pm 300^{*}$ & $18250-16450$ & ZK0714 & \\
\hline Layer No. 2 & Shell & $12845 \pm 130^{*}$ & $15950-14350$ & BK83009 & \\
\hline \multicolumn{6}{|c|}{ Huangyandong in Fengkai, Guangdong Province } \\
\hline Cave Hall & Shell & $11580 \pm 300^{*}$ & $12050-13150$ & ZK0676 & \multirow{2}{*}{$\begin{array}{l}\text { A piece of incomplete polished } \\
\text { stone tool and perforated stone } \\
\text { tools. }\end{array}$} \\
\hline Cave Hall & Shell & $10640 \pm 300^{*}$ & $13250-11350$ & ZK0677 & \\
\hline \multicolumn{6}{|c|}{ Zengpiyan in Guilin, Guangxi Province } \\
\hline BT37 & Charcoal & $8790 \pm 170$ & $10250-9450$ & BA01224 & Polished adze \\
\hline \multicolumn{6}{|c|}{ Shangshan in Pujiang, Zejiang Province } \\
\hline 2001PKF2 & Pottery & $8740 \pm 110$ & $10200-9500$ & BA02235 & \multirow{4}{*}{$\begin{array}{l}\text { Partial or entirely polished axe } \\
\text { and adze, with stone balls, } \\
\text { chopper, pottery. }\end{array}$} \\
\hline 2001PKH31F & Pottery & $9610 \pm 160$ & $11350-10400$ & BA02236 & \\
\hline 2001PKT26) & Pottery & $8620 \pm 160$ & $10200-9250$ & BA02237 & \\
\hline 2001PKT3(2) & Pottery & $8050 \pm 110$ & $9300-8550$ & BA02238 & \\
\hline
\end{tabular}

Tab. 1. The dates of earlier polished lithic implements in China (Wu \& Zhao 2003). 


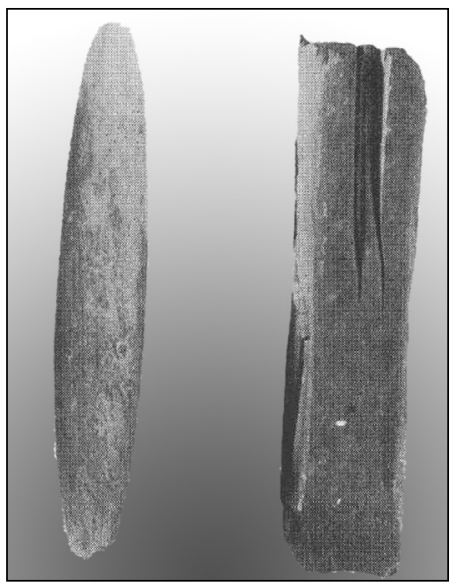

Fig. 4.2. Polished shuttle-shaped stone tools from the Xian-rendong site (Jiangxi Provincal Committee for Administration of Cultural Relics 1963).

pers. Several of them are polished, mostly rollers and perforated stone tubes (Fig. 6.2). The raw material they used to produce them is black shale, which is not very hard. Only one axe was found (Fig. 6.1), of uncertain function, is of grayish-green claystone, entirely polished with one cutting edge, which has been damaged by use. It is $8 \mathrm{~cm}$ long $4 \mathrm{~cm}$ wide and $0.85 \mathrm{~cm}$ thick.

\section{CONCLUSION}

According to the discoveries of polished stone tools in South China, different kinds of polished stone tools appeared at different times. The earliest polished stone tools are axes, adzes and cutters, all having only the blade polished. The cone-shaped or shuttle-shaped polished tools, used for perforating, are also among the earliest polished stone tools. According to the radiocarbon dates from the sites of Bailiandong and Liyuzui, the ages assigned to these kinds of stone tools are about 24 000-22 000 calBP, based on samples of calc-sinter and shells. If we consider the "dead carbon factor" concerning the calcsinter and shells in the limestone area of South China, we should subtract some years from those dates. The dead carbon factor in aquatics and hydrophytes in South China has been measured before. It changes from a hundred years to two thousand years or more. The mean value of the factor is about 1500

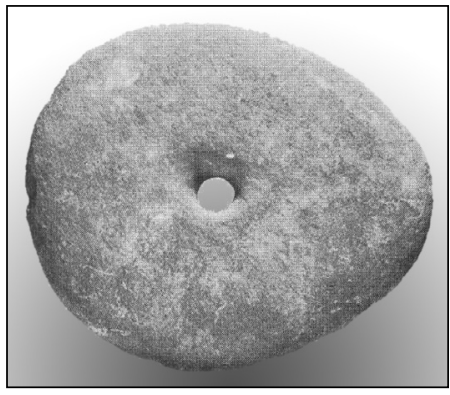

Fig. 4.3. Perforated stone tool from the Xianrendong site (Jiangxi Provincal Committee for Administration of Cultural Relics 1963). years (14C Laboratory of Archaeological Department 1982; Zhang Xuelian 2003). Here we use 3000 years as the greatest factor. Then the ages of the earliest stone tools with only the blade polished are about $21000-19000$ cal. BP. Cone-shaped or shuttle-shaped polished stone tools appeared at almost the same time. The evolution of polished stone tools followed steps: blade polished only; entire tool roughly ground, with blade finely polished; entirely polished. The completely polished stone tools appeared about $10000 \mathrm{cal} \mathrm{BP}$. Those from the Zengpiyan site date to $10250-9450 \mathrm{cal}$ BP. The polished adze was embedded in 5, upper layer. The stone tools from phase 1-4, lower layers, are all chipped. The dates of Pengtoushan culture and Chengbeixi culture along the Yangtse River are 9800-7500 cal BP. A few polished stone tools were found there. The stone assemblage consists of chipped tools and a large number of adornments, and very few tools such as small axes, adzes and chisels.

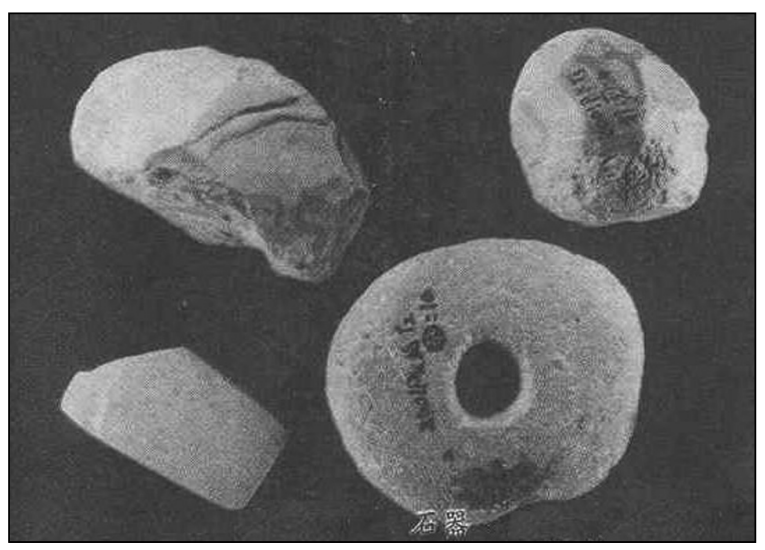

Fig. 5. Polished adze and perforated stone ware found in Shangshan site (Jiang 2003).

The development of stone polishing technology can be seen from changes in the materials of stone wares. The earlier polished stone tools were usually made of sandstone, shale and tuff, which are all soft and easily worked. Metamorphic rock and other hard rocks were used to make stone tools later. Of course, the selection of stone material was also limited by local resources. Anyway, the hard material used for stone tool making show the progress of polishing technology. Usually the stone tools used for felling, cutting, scraping and digging were made from the hard rock. Most of the early polished stone tools were made of pebbles after polishing. The natural surface of the pebble can be seen from the axe, adze and cutter with the blade polished only.

According to finds made so far, the appearance of the polishing technology predates the cultivation of 


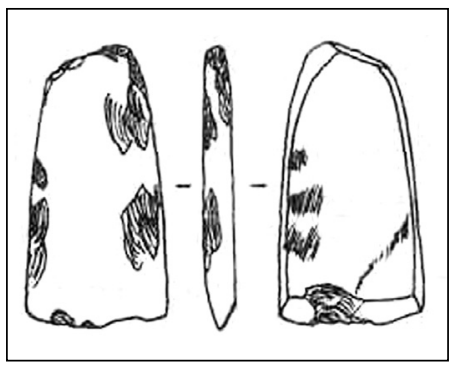

Fig. 6.1. Polished

axe from the

Pengtoushan site

(Institute of Cultural Relics and Archaeology in Hunan Province 1990).

rice. Because of insufficient dates it is still difficult to make a comparison between the appearances of polished stone tools and pottery. It seems that the polished stone tools were earlier than the pottery in some places. But we also found contrary evidence, such as at the Zengpiyan site. The pottery shards were excavated from phases 1-4, lower layers, without any polished stone tools. The polished stone tools appeared later, in phase 5, upper layer.

There is no doubt that the appearance of polished stone tools is a Neolithic characteristic in South China, because polished stone tools were found in almost every Paleolithic-Neolithic transition site in South China. But the function of the polished stone tools in the transition is still uncertain. The development of the polishing technology covered a long
Fig. 6.2. Stone club-shaped pendant stone tube and stone clubshaped pendant from the Pengtoushan Site (Institute of Cultural Relics and Archaeology in Hunan Province 1990).

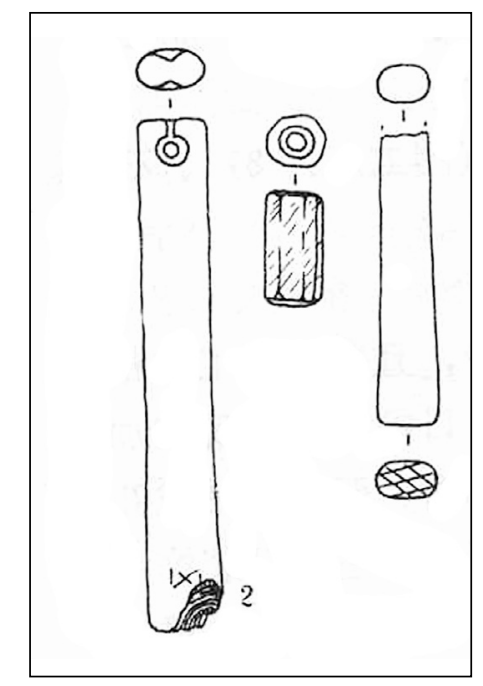

period from its appearance to its wider distribution. The process varied from place to place. More detailed information is needed in order to understand the relationship between the appearance of polishing technology and economic development, the relationship with living conditions and the environmental background, the relationship to the appearance of pottery, agriculture and husbandry. We must also investigate the process in the context of the global development of stone tool making technology.

\section{REFERENCES}

ARCHAEOLOGICAL INSTITUTE, CASS. 1991. Zhongguo Kaoguxue zhong Tanshisi Niandai Shujuji (The collection of radiocarbon dates in Chinese Archaeology) (1965-1991). Cultural Relics Publishing House. Beijing (in Chinese).

14C LABORATORY OF ARCHAEOLOGICAL DEPARTMENT, PEKING UNIVERSITY (by Chen Tiemei et al.) 1982. The reliability of the radiocarbon dating for the limestone area and the chronological problem related with Zengpiyan site. Kaoguxuebao 2: 243250 (in Chinese).

14C LABORATORY OF ARCHAEOLOGICAL DEPARTMENT, PEKING UNIVERSITY (by Yuan Sixun et al.). 1987. Report on 14C Date (7), Wenwu 11 (in Chinese).

GLYN DANIEL 1987. A Hundred And Fifty Years of Archaeology? Chinese Edition, translated by Huang
Qixu and An Zhimin 1987. Culture Relics Press. Beijing.

INSTITUTE OF CULTURAL RELICS AND ARCHAEOLOGY IN HUNAN PROVINCE 1990. The brief excavation report of early Neolithic site of Pengtoushan in Li County in Hunan Province. Wenwu 8: 17-29 (in Chinese).

JIANG LEPING et al. 2003. An early Neolithic site about 10,000 BP found in Pujiang County, Zhejiang Province. Zhongguo Wenwubao November 7 th (in Chinese).

JIANGXI PROVINCAL COMMITTEE FOR ADMINISTRATION OF CULTURAL RELICS 1963. Jiangxi Wannian Dayuan Xianrendong yizhi sjhijue (Test excavation at the Xianrendong cave site in Dayuan, Wannian, Jiangxi). Kaogu Xuebao 1: 1-16 (in Chinese). 
JIANGXI PROVINCAL MUSEUM 1976. Jiangxi Wannian Dayuan Xianrendong yizhi di'erci fajue baogao (Report on the second excavation at the Xianrendong cave site in Dayuan, Wannian, Jiangxi). Wenwu 12:12-23 (in Chinese).

LI XINGGUO, LIN GUANGLIAN, XU GUOYING, WANG FULIN and LI FENGXIANG 1987. Liuzhou Dalongtan Beiqiu Yizhi Niandai Jiqi yu Lingjin Diqu Duibi (The dates of shell mound sites in Dalongtan in Liuzhou with the comparison of neighboring regions). Disiji Bingchuan yu Disiji Dizhi Lunwenji (disiji) (Collection of papers on Quarternary glacier and Quarternary geology) 4: 229-234, Geological Science Press. Beijing (in Chinese).

LIUZHOU MUSEUM 1983. Liyuzui Neolithic shellmound Site in Dalongtan, Liuzhou. Kaogu 9: 769774 (in Chinese).

QIU LICHENG et al. 1982. Excavation on Dushizai Neolithic Cave site in Yangchun, Guangdong. Kaogu 5: 456-459, 475 (in Chinese).

SCIENTIFIC MUSEUM OF LIUZHOU BAILIANDONG CAVE, et al. 1987. Excavation report on Guangxi Liuzhou Bailiandong cave relics at Stone Age. Southern Nationality Archaeology, Vol. 1 (in Chinese).

SONG FANGYI et al. 1983. Huangyandong Cave site in Fengkai, Guangdong. Kaogu 1:1-3 (in Chinese).

XIAOHONG WU and CHAOHONG ZHAO 2003. Chronology of the Transition From Palaeolithic to Neolithic in China. The Review of Archaeology 24/2: 15-20.
YUAN SIXUN, CHEN TIEMEI, GAO SHIJUN and MA LI 1990. Yang Chun Dushizai he Liuzhou Bailiandong Yizhi de Niandai Ceding-Shitan Huannan Diqu Jiushiqi Wenhua xiang Xinshiqi Wenhua Guodu de Shijian (Dating of Dushizai Cave site in Yangchun and Bailiandong Cave site in Liuzhou - Exploration of Transition from the Paleolithic to Neolithic Period in South China). Jinian Beijing Daxue Kaogu Zhuanye Shanshi Zhounian Lunwenji (Collected Works for the Thirtieth Anniversary of the Archaeology Speciality of Peking University) (1952-1982): 4047. Cultural Relics Publishing House. Beijing (in Chinese).

ZHANG CHI 2000. Jiangxi Wannian Zaoqi Taoqi he Daoshu Zhiguishi Yicun (Pottery and silicified rice remains in Wannian County, Jiangxi Province). Diaozuo Taoqi he Dushi de Qiyuan (The Origin of Rice Agriculture, Pottery and Cities): 43-50. Cultural Relics Publishing House. Beijing (in Chinese).

ZHANG XUELIAN et al. 2003. The excavation report of the Zengpiyan site: 429-445. Cultural Relics Publish House (in Chinese).

ZHAO ZHIJUN 1998. The middle Yangtze Region in China is one place where rice was domesticated: phytolith evidence from the Diaotonghuan cave, northern Jiangxi. Antiquity 72/278: 885-897.

ZHOU GUOXING 1994. Another Discussion on Bailiandong Culture. Proceedings of International Seminar on the Relations of Ancient People and Prehistoric Culture Between China and Japan: 203-264, China Radio International Press. Beijing (in Chinese). 